\title{
The Impact of Imports and Exports on the Size and Composition of Government Expenditures
}

\author{
Michael Benarroch ${ }^{1} \&$ Manish Pandey ${ }^{2}$ \\ ${ }^{1}$ Asper School of Business, University of Manitoba, Winnipeg, Canada \\ ${ }^{2}$ Department of Economics, The University of Winnipeg, Winnipeg, Canada \\ Correspondence: Michael Benarroch, Asper School of Business, University of Manitoba, Winnipeg, Manitoba, \\ R3T5V4, Canada. Tel: 1-204-474-9209. E-mail: m.benarroch@umanitoba.ca
}

Received: January 3, 2017

Accepted: January 26, 2017

Online Published: February 15, 2017

doi:10.5539/ijef.v9n3p57

URL: http://dx.doi.org/10.5539/ijef.v9n3p57

\begin{abstract}
This paper examines the casual relationship between greater exposure to international trade and the size and composition of government expenditures, productive versus unproductive. To capture differential impacts on how government responds to greater international exposure three measures are used: the ratio of exports plus imports to GDP (openness), the ratio of exports to GDP, and the ratio imports to GDP. For all countries in aggregate, we find no causal relationship between openness and total government expenditures or productive and unproductive expenditures. For low-income countries however, there is a positive causal relationship between openness and productive government expenditures. Further, there is a positive causal relationship between the import ratio and productive expenditures for all countries as well as for low- and high-income countries separately. Exports, conversely, have no causal relationship with any measure of government expenditures. Our findings suggest that governments in economies with greater imports as a share of GDP increase productive expenditure to counteract the negative consequences from more exposure to foreign competition.
\end{abstract}

Keywords: government size, openness, causality

\section{Introduction}

There is an extensive debate in the literature on the relation between openness and government size. Much of the debate centers on the issue of whether an increase in openness leads to larger government size and the reasons for why this may occur. Rodrik (1998) claims that open economies tend to have larger governments because countries exposed to greater "external risk" demand larger governments as a form of social insurance. To support his claims, Rodrik (1998) presents empirical evidence that shows a positive relationship between greater openness and the size of government. The findings, however, do not identify the specific categories of government expenditures that increase with greater openness. Based primarily on Rodrik's findings, much of the ensuing literature has focused on verifying whether greater openness is positively related to government size and identifying the categories of government expenditures that respond to an increase in openness. In general, there is a lack of consensus in the literature with respect to these two issues; and, in particular, with respect to the latter. The current paper examines the ways in which categories of government expenditure respond to changes in openness. Specifically, we examine the relation between openness and productive and unproductive government expenditures and find that it is primarily productive government expenditures that increase with openness, in particular, with increase in imports. Further, this association is found to be prevalent for low-income rather than high-income countries.

While Rodrik (1998) proposed the social insurance hypothesis to explain the actions of governments in the face of greater openness, the literature goes well beyond just an examination of Rodrik's hypothesis as the only explanation for why openness leads to larger government size. There are now numerous alternative explanations for this relationship ranging from country size, to capital mobility, foreign direct investment, economic integration, terms of trade effects, and variety of imported goods (Note 1). Most of these studies find a positive link between openness and government size but not necessarily due to the reasons suggested by Rodrik (1998). A few recent studies employ disaggregated government expenditures to determine whether the link to greater openness is associated with a particular sub-category of aggregate government spending that is linked to social security. Gemmell et al. (2008), for example, using data for 25 OECD countries conclude that increases in 
foreign direct investment do shift government expenditure towards social spending. Conversely, Shelton (2007) and Benarroch and Pandey (2012) find that openness leads only to greater spending on education and solely in low-income countries, while Dreher et al. (2008) find that openness is not associated with an increase in social spending.

Based on this literature, there appears to be some doubt that governments spend more on social security as a result of greater openness. Within this literature however, the empirical results are found to be sensitive to the empirical method employed, the variable definitions, the set of countries employed (developed versus less developed) and the time frame. The question then remains as to what categories of government expenditure may respond to increases in openness.

In the current paper we extend the literature by examining whether openness has a differential casual impact across two disaggregated categories of government expenditure, productive versus unproductive expenditures, and whether the impact of openness on these two categories is the same across both low-income and high-income countries. Unproductive government expenditures are defined as spending on current consumption, for example social welfare transfers, whereas government expenditures on productive services increase the productivity of capital and are hence growth enhancing (Barro, 1990). Kneller et al. (1999) categorize government expenditures as unproductive and productive expenditures to examine the prediction of the endogenous growth model with the composition of government expenditures proposed by Barro (1990). They confirm the predictions of the Barro model. To our knowledge this paper is the first to examine whether there are differences in the response of productive versus unproductive government expenditures to increase in openness.

The motivation for this approach is driven by the desire of governments to invest in improving productivity of capital in the face of greater international competition (Barro, 1990). Openness leads to greater exposure to international competition. As tariffs and other protectionist measures are removed domestic producers face greater competition from external producers. Sectors that were previously protected through tariff walls (or subsidies) suddenly face greater foreign competition. As protectionism is removed economic adjustments will naturally occur across sectors of the economy. Sectors with a comparative advantage will expand in size while sectors without a comparative advantage will contract. This is of course part of the explanation provided by Rodrik (1998) as to why countries exposed to greater "external risk" demand larger governments as a form of social insurance. Greater openness may however, motivate governments to try and raise economic growth or improve competitiveness rather than spend on social services. It is plausible that governments respond to greater openness by spending on productive services to improve competitiveness and take advantage of available export opportunities or counteract import competition from foreign markets.

In general, one should expect countries with the highest levels of protectionism to show the greatest response when protectionism is removed, since these countries are likely the ones facing the largest adjustments. There is ample evidence showing that low-income countries (less developed countries) have generally been more protectionist than high-income countries (developed countries) (see Pannagariya, 2003; IMF, 2001; and World Bank, 2010; Table 6.8). This likely implies that low-income countries are generally less competitive and have more to lose from becoming more open and allowing a greater amount of imports. According to Paulino and Thirlweall (2004) trade liberalization between 1972 and 1997 raised import growth by more than export growth worsening the balance of payments for 22 less developed countries. This may explain why some studies mentioned above have found that greater openness leads to higher government expenditures in low-income rather than high-income countries.

The World Bank (2010), also shows that low-income countries generally export a smaller variety of goods. In particular, the five top exported goods of Sub-Saharan, low-income and middle-income countries range from $74 \%$ to $58 \%$ of total exports; compared to $50 \%$ for high-income countries. Loss of export markets or greater import competition from one of these five goods therefore has a much larger impact on the economies of low-income countries relative to high-income countries. Moreover, there is evidence to show that as openness has grown, exports from high-income countries have grown relative to exports from low-income countries (IMF (2001)). As a result, we would expect governments in low-income countries to react more than high-income countries to offset some of the adjustments that occur with greater openness.

Given this evidence, there could be differences in the relation of imports and exports with government expenditures and between low-income and high-income countries. Governments may react differently to changes in imports compared to exports. Hence in the current paper we empirically examine the effects of imports versus exports on productive and unproductive expenditures separately. In addition, we also empirically examine whether the response to increased openness differs between low-income and high-income countries. 
To determine whether there are causal relationships between variables, we use cross-country panel data from the Easterly (2001) Government Financial Statistics and estimate dynamic panel data models (Arellano \& Bover, 1995; Blundell \& Bond, 1998). These models determine causality by examining whether, after controlling for lagged values of the dependent variable, lagged values of the independent variable are informative in determining the current values of the dependent variable (Note 2). Easterly (2001) provides information on total government expenditure and expenditure by functional categories as a percentage of GDP for 94 countries over the period ranging from 1972 to 2000. Our empirical study yields a number of interesting results that to our knowledge are not found elsewhere in the literature. To begin, we find a positive causal relationship between openness and productive government expenditures for low-income countries but not for high-income countries or the world as a whole.

Secondly, when we separately investigate the potential differences in the relationship between imports versus exports and government expenditures, we find that imports have a positive causal relationship with productive expenditures for both low-income and high-income countries. There is however, no evidence of a causal relationship between imports and unproductive expenditures. In other words, governments in both high and low-income countries respond to greater imports by increasing productive expenditures. By doing so, they are responding to greater import competition by attempting to raise productivity and stimulate economic growth rather than increasing social expenditures.

Finally, we find no evidence that exports have a causal relationship with government size regardless of whether we consider all countries or low-income countries. Overall, our findings provide evidence of differences in the relationship between exports and imports and government expenditures; governments respond more to imports than exports and they do so by increasing productive expenditures. This is likely due to the greater political pressure that governments face when dealing with growing imports because of their perceived negative impact on local labor markets. For example, Autor, Dorn, and Hanson (2013) find that between 1990 and 2007 one quarter of the rise in US manufacturing unemployment can be explained by the import competition.

In many respects, our paper fits into a growing empirical literature that finds a positive relationship between openness and government size for reasons other than those suggested by Rodrik (1998) and finds a differential relationship across countries with dissimilar characteristics. For example, Alesina and Warcziarg (1998) determine small countries are more open and have larger governments compared to large countries, Epifani and Gancia (2009) find that greater openness leads to a terms of trade effect that lowers the domestic cost of taxation and leads to larger governments in countries with a low elasticity of substitution between domestic and foreign goods, whereas Hanslin (2010) finds that the "number of different imported products" has a positive impact on government size in OECD relative to non-OECD countries. The current paper finds that governments respond to greater openness by increasing productive expenditures. There are however, differences in the response to imports compared to exports and between low-income and high-income countries

The rest of the paper is organized as follows. Section 2 provides the description of the data and the definition of the variables used for the analysis. Section 3 provides a discussion of our methodology and our findings. Section 4 provides a brief conclusion.

\section{Data Sources and Summary Statistics}

The Government Financial Statistics (GFS) dataset provided by the International Monetary Fund (IMF) and complied by William Easterly provides data on total government expenditure as well as government expenditure by functional categories as a percentage of GDP for about 94 countries for the period ranging from 1972-2000 (Note 3). Data on trade, exports and imports, GDP and real GDP per capita are obtained from World Development Indicators (WDI). In addition to the traditional definition of openness, exports plus imports divided by GDP, to separately examine the effects of exports and imports on government expenditure, we also use exports divided by GDP and imports divided by GDP as measures of openness.

To account for the long-run relationships between variables, we follow Shelton (2007) and smooth short-run fluctuations by taking five-year averages of all variables. Shelton (2007) argues that the choice of 5-year averages is a common compromise in the growth literature. For the GFS data, this provides an unbalanced panel dataset with a maximum of 6 observations for each country in our dataset. The periods over which averages are computed are 1970-75, 1976-80, 1981-85, 1986-90, 1991-95 and 1996-2000. Further, to investigate whether there are differences between low and high income countries, we define low income countries using the World Bank definition based on real Gross National Income (GNI) per capita for the year 2000 and obtain the data from the WDI (Note 4). The World Bank definition based on real GNI per capita (GNIpc) in US dollars for the year 2000: low income countries - GNI pc $<=\$ 755$, lower middle income countries $\$ 756<$ GNIpc $<\$ 2995$, upper 
middle income countries $\$ 2996<$ GNIpc $<\$ 9265$, high income countries $>\$ 9265$. We classify a country as low income if it belonged to the first two groups (low income or lower middle income), that is if GNIpc for the country in 2000 was less than $\$ 2596$. We used a number of cutoffs for per capita income and the findings were qualitatively similar to those reported in the paper. The results for the estimation are available from the authors upon request.

Using data on government expenditures by functional categories, we follow Kneller et al. (1999) and define productive and unproductive government expenditures as follows:

- Productive Expenditures $=$ public + defense + education + health + housing + transport

- Unproductive Expenditures = social security + recreation + economic services (other than transport)

For the analysis of the causal relationships between trade and the composition of government expenditures, productive or unproductive, we restrict the sample to countries for which we have an adequate number of observations to examine the relationship. Our sample includes 68 countries with 30 low-income countries and 38 high-income countries. The list of countries is provided in Table A1 of Appendix A. Table 1 provides the average values of government expenditures for the countries in our sample. Productive and unproductive government expenditures on average account for approximately $82 \%$ of total government expenditures; and thus the majority of government expenditures are covered by productive and unproductive expenditures. Table 1 indicates that high-income countries (HICs), which have more established welfare systems, have a higher share of unproductive expenditures in total expenditures. This as Garrett (2001) argues, is because with higher national income, they are able to spend a greater share of GDP on unproductive expenditures. Further, while total, productive and unproductive expenditures are highly correlated (bottom panel of Table 1), the correlation is greater for low-income countries (LICs).

Table 1. Average total, productive and unproductive expenditures (\% of GDP)

\begin{tabular}{llll}
\hline & All & HIC & LIC \\
\hline Total Expenditures (TE) & 30.73 & 34.07 & 25.41 \\
Productive Expenditures (PE) & 13.87 & 14.33 & 13.15 \\
Unproductive Expenditures (UE) & 11.41 & 13.75 & 6.90 \\
Corr(TE, PE) & 0.749 & 0.716 & 0.908 \\
Corr(TE, UE) & 0.785 & 0.755 & 0.819 \\
\hline
\end{tabular}

Note. author calculations using data described in Section 2.

Similar to the current study, Garen and Trask (2005) consider the influence of differential levels of income on the relationship between openness and government size. They find that "poor and rich countries have different institutions and it is worthwhile to examine inter-relationships with a country's income" (p. 542). Garrett (2001) came to a similar conclusion when examining the differential effect between low-income income countries versus high-income countries. According to Garrett (2001) "it seems reasonable to hypothesize that the purported efficiency constraints of globalization are likely to become more evident as one moves from the OECD to less developed nations" (p. 4).

Table 2 provides the average for total trade, imports and exports as a percentage of GDP. As is evident, trade openness is higher for HICs than LICs. Exports and imports as a percentage of GDP are similar within the HICs, whereas LICs have lower exports than imports as a percentage of GDP. Further, there is high correlation between total trade, imports and exports for both HICs and LICs.

Table 2. Average total trade, import and exports (\% age of GDP)

\begin{tabular}{llll}
\hline & All & HIC & LIC \\
\hline Total Trade & 78.25 & 89.16 & 60.88 \\
Imports & 40.13 & 44.15 & 33.74 \\
Exports & 38.11 & 45.01 & 27.13 \\
Corr(Open, Import) & 0.981 & 0.996 & 0.922 \\
Corr(Open, Export) & 0.983 & 0.996 & 0.879 \\
\hline
\end{tabular}

Note. author calculations using data described in Section 2. Total Trade = Imports + Exports. 
Correlations between openness measures (total trade, imports and exports) and expenditure measures (total, productive and unproductive) for all countries in our sample are provided in Table 3 . While imports and exports are highly correlated with total trade, there are significant differences across the correlations with expenditure measures. In particular, productive expenditures have a higher positive correlation with the openness measures than unproductive expenditures. Further, productive expenditures have a higher correlation with imports than exports. These differences motivate our separate examination of the causal relationships between the openness measures and the expenditure measures.

Table 3. Correlation between openness and government expenditure measures

\begin{tabular}{lllllll}
\hline & Total Trade & Imports & Exports & Total Expdr & Prod Expdr & Unprod Expdr \\
\hline Total Trade & 1.000 & & & & & \\
Imports & 0.981 & 1.000 & & & & \\
Exports & 0.983 & 0.928 & 1.000 & & & \\
Total Expdr & 0.179 & 0.196 & 0.156 & 1.000 & & \\
Prod Expdr & 0.325 & 0.370 & 0.271 & 0.749 & 1.000 & 1.000 \\
Unprod Expdr & 0.044 & 0.022 & 0.064 & 0.785 & 0.280 & \\
\hline
\end{tabular}

Note. author calculations using data described in Section 2. Total Trade $=$ Imports + Exports; Total Expdr $=$ total government expenditures to GDP ratio; Prod Expdr = productive government expenditures to GDP ratio; Unprod Expdr $=$ unproductive government expenditures to GDP ratio.

\section{Empirical Approach and Findings}

\subsection{Dynamic Panel Data Estimation}

To determine 'Granger' causality between government expenditure measures and openness measures, appropriate instruments at the country level and over time are required. Given that such instruments are not readily available, we use dynamic panel regression models to resolve the issue of instruments by using suitable lagged levels and lagged first differences of the regressors as instruments. Following Benarroch and Pandey (2012), Casu and Girardone (2009), Hartwig (2010) and Michauda and van Soest (2008) we employ the following dynamic regression equation to examine the causal relationship between the openness measures and the government expenditure measures:

$$
y_{i t}={ }_{0}+{ }_{p=1}^{m} y_{i t p}+{ }_{p=1}^{m} x_{i t p}+p d_{-} d u m+{ }_{i}+{ }_{i t} .
$$

Equation (1) is an $\operatorname{AR}(\mathrm{p})$ process with country-specific fixed effects $(\eta)$ and period dummies (pd_dum). The causality test is based on a joint test Ho: $\beta_{1}=\beta_{2}=\ldots=\beta_{p}=0$, where not accepting the null hypothesis provides evidence for $x$ 'Granger' causing $y$. It is important to note that Granger causality tests according to Casu and Girardone (2009) "only indicate that changes in one variable precede changes in another variable of interest (with a positive or negative sign) rather than establishing causation in the traditional sense of the word" (pp. 136,). In other words, if the history of $x$ improves the prediction of $y$, given the history of $y$, then $x$ causes $y$. Given that the history of $y$ will include the effects of other variables and we include country-specific fixed effects, which controls for all persistent differences across countries, we do not include other control variables in Equation (1).

There are several advantages in using the dynamic panel data estimator for examining the causal relationship between openness and government expenditure: 1) it is designed for small-T large-N panels, which is consistent with the cross-country panel data that we use for our analysis; 2) it allows for the lags of the dependent variable to be included as explanatory variables; 3 ) it addresses endogeneity by allowing for independent variables that are not strictly exogenous; 4) it allows for country-specific fixed-effects; and 5) it allows for heteroskedacity and autocorrelation of variables within the panel. Benarroch and Pandey (2012) and Hartwig (2010) for further details on this issue.

It is necessary that the time series for both the dependent and the independent variable be stationary in order to test for Granger-causality. We examine the time series properties of the 5-year averages of government expenditure measures, and trade openness measures using panel data unit root tests (augmented Dickey-Fuller test) and find that all series are stationary. We undertake the tests using the xtunitroot command in Stata and find 
that the null hypothesis that the data contains a unit root is rejected for the three government expenditure measures and the three trade openness measures. Further, to determine the optimal lag length, regression (1) is estimated using OLS with the choice of the optimal lag length is based on the Schwarz Information Criterion (SIC). Following Hartwig (2010), the optimal lag length is found to be two periods or ten years.

Equation (1) is estimated using the system GMM estimator initially developed by Blundell and Bond (1998) and refined by Roodman (2009a) and Cavallo and Cavallo (2010). The estimation procedure employs variables in levels and first differenced lagged values as instruments. Roodman (2009a) argues that the system GMM approach is more efficient than the difference GMM estimator developed by Holtz-Eakin et al. (1988). The system GMM approach addresses the problem of weak instruments, which arises for difference GMM estimators when variables are very persistent. The estimator allows us to address the endogeneity of explanatory variables in a dynamic formulation and explicitly controls for potential biases arising from country-specific effects. Given the small sample size, we use the small sample correction proposed by Windmeijer (2005) and report robust two-step standard errors for all the regressions.

To examine the validity of the instruments for the system GMM estimation model, two specification tests are performed: an over-identification test and a serial correlation test. Chang et al. (2009) provide details on the tests for validity of instruments in system GMM estimation models. The over-identification test, the Hansen test, is a test for the validity of the full set of instruments. For this test, not rejecting the null hypothesis of no over-identification provides support for the model. The serial correlation test, the AR2 test, assesses whether the first-differenced error term is second-order serially correlated. This would imply that the error term follows a moving average process leading to a rejection of lagged values as appropriate instruments. Not rejecting the null of the absence second-order serial correlation lends support to the system GMM estimation model.

As argued by Roodman (2009b), a problem with system GMM estimation models is that a large number of instruments over fit endogenous variables and at the same time weaken the Hansen test for over-identification; the problem is referred to as instrument proliferation. Given that there are no formal tests for determining the number of lags that should be used as instruments; Roodman recommends two ways for reducing the number of instruments. First, combine instruments through addition into smaller sets (collapse instruments), and second, limit the number of lagged values to use as instruments. To avoid instrument proliferation, we collapse the number of instruments for all specifications. Collapsing instruments reduces the number of instruments without significant loss of information obtained from the instruments. In addition, for endogenous variables, as is conventional, we use lags of only two periods or greater as instruments (Roodman, 2009a). This further reduces the number of lags for the regression models that we estimate and helps address the problem of instrument proliferation.

\section{Results}

\subsection{Trade Openness}

Much of the literature on openness and government size defines openness as the sum of exports and imports divided by GDP (Note 4). In his seminal paper on openness and government size however, Cameron (1978) clearly articulates alternative means by which exports and imports could separately impact government size. In essence, he argues that a greater dependence on exports "may limit the government's ability to manage aggregate demand and control levels of unemployment and capital formation" (Cameron, 1978, p. 1250). Alternatively, high levels of imports "remove decisions regarding the production and pricing of goods from domestic markets," can lead to imported inflation, and "may contribute to balance of payments deficits" (Cameron, 1978, p. XX)." In spite of these alternative means by which exports and imports impact government size, Cameron (1978) did not separately test for the effects of exports and imports.

Likewise, Rodrik (1998) also explicitly identifies a differential role for exports and imports. In particular, he considers the impact of imported intermediate goods on government size. He states "that by making domestic productivity a function of imports we have captured one plausible channel through which trade risk spills over to the domestic economy" (Rodrik, 1998, p. 1012). He continues by observing that there is strong evidence of this spillover effect found in the data. The model shows that when there is an increase in the riskiness of exports we get a reallocation of the economy's resources toward the safe activity (government). Though Rodrik (1998) uses the traditional definition of openness for his analysis, he does discuss and calculate a measure purely related to export exposure.

Theoretical considerations in this literature (Rivera-Batiz \& Romer, 1991), Grossman and Helpman (1990) and Romer $(1986,1990)$ generally focus on the relationship between international trade and growth. Interestingly, the empirical literature on economic growth finds a strong link between openness and economic growth, also 
identifies a differential impact for exports versus imports. Levine and Renelt (1992) for example, conclude that imports and total trade have an impact on growth. Building on Levine and Renelt (1992), Ghali (1999) uses the ratio of imports to GDP and the ratio of exports to GDP separately when conducting Granger Causality tests on government size and economic growth. He concludes that, "exports and imports do not have the same causal links with growth" (p. 986). Finally, Yanikkaya (2003) also shows that alternative measures of trade intensity, including separate measures for exports and imports, have a differential impact on growth within less developed countries.

There thus, appears to be significant evidence that imports and exports can have differential impacts on an economy. This is certainly the case for economic growth, though as Cameron (1978), and to some extent Rodrick (1998), hypothesized it also extends to government size. The current paper therefore, extends the literature on openness and government size by examining whether there exits a causal relationship separately for imports versus exports, and either total, unproductive or productive government expenditures. Further, we consider whether the effect of openness on government expenditures holds for all countries, or only separately for low-income and higher-income countries. Throughout the paper we use the World Bank definition based on Gross National Income (GNI) to classify countries are low income or high income.

To evaluate the relationship between government expenditures and trade, we estimate regression equation (1) using the approach discussed above with the logarithm of the ratio of total, productive or unproductive government expenditures to GDP as the dependent variables. Table 2 provides the estimation results for all countries in aggregate as well as separately for low-income and high-income countries. Data for the estimation is available for 68 countries -30 low income countries and 38 high income countries. For almost all specifications, the p-values for the Hansen and the AR2 tests suggest that the null hypotheses of no over identification and the absence second-order serial correlation are not rejected (Note 5). This implies that lagged values of the variables can be used as instruments.

Based on the estimation results for all countries, the causality tests reported in the last row of Table 4 indicate that there is no evidence of a causal relationship between openness and total expenditures (the p-value for the test is 0.77). This result is not new to the literature and while similar to that found in Benarroch and Pandey (2012) is in contrast to Rodrik (1998).

Table 4. Causality tests: openness and total, productive and unproductive expenditures

\begin{tabular}{lccccccccc}
\hline & \multicolumn{3}{c}{ All Countries } & \multicolumn{3}{c}{ Low Income Countries } & \multicolumn{3}{c}{ High Income Countries } \\
\cline { 2 - 10 } Variable & Total & Prod & Unprod & Total & Prod & Unprod & Total & Prod & Unprod \\
\hline L1.open & 0.097 & 0.612 & -0.512 & 0.341 & 0.423 & 0.358 & -0.324 & 0.912 & -0.248 \\
& $(0.43)$ & $(0.36)^{*}$ & $(1.00)$ & $(0.14)^{* *}$ & $(0.28)$ & $(1.12)$ & $(0.21)$ & $(0.57)$ & $(0.43)$ \\
L2.open & 0.063 & -0.051 & 0.126 & -0.004 & 0.024 & -0.759 & 0.225 & -0.188 & 0.051 \\
& $(0.13)$ & $(0.11)$ & $(0.32)$ & $(0.24)$ & $(0.24)$ & $(0.43)^{*}$ & $(0.21)$ & $(0.18)$ & $(0.26)$ \\
Observations & 184 & 184 & 164 & 71 & 71 & 54 & 113 & 113 & 110 \\
Countries & 68 & 68 & 63 & 30 & 30 & 25 & 38 & 38 & 38 \\
Instruments & 14 & 14 & 14 & 14 & 14 & 14 & 14 & 14 & 14 \\
Hansen p-value & 0.17 & 0.43 & 0.83 & 0.16 & 0.45 & 0.39 & 0.34 & 0.19 & 0.20 \\
AR2 p-value & 0.80 & 0.59 & 0.92 & 0.80 & 0.39 & 0.21 & 0.57 & 0.37 & 0.60 \\
Causality tests (p-values) & & & & & & & & 0.37 \\
Test $\beta_{1}=\beta_{2}=0$ & 0.77 & 0.22 & 0.88 & 0.01 & 0.08 & 0.16 & 0.30 & 0.26 & 0.69 \\
\hline
\end{tabular}

Note. standard errors in parenthesis below estimates. ${ }^{*}$ Significant at $10 \%, * *$ Significant at $5 \%$, and $* * *$ Significant at $1 \%$. Total $=$ total government expenditures to GDP ratio; Prod = productive government expenditures to GDP ratio; Unprod = unproductive government expenditures to GDP ratio. First and second lags of dependent variable, logarithm of revenue to GDP ratio, included in all regressions, the estimates are not reported. Time dummies and a constant are included in all regressions, estimated coefficients not reported. Estimation method: two-step system GMM with Windmeijer (2005) small sample robust standard error correction with collapsed instruments.

A similar result is also found for high-income countries when productive and unproductive expenditures are separated. In other words, there is no casual relationship between productive or unproductive government expenditures and openness within high-income countries. In the case of high-income countries the disaggregation of government spending makes no difference to the results. 
The results however, do change with respect to low-income countries. They suggest a positive causal relationship between openness and total government expenditures and productive expenditures but not between openness and unproductive expenditures. In other words, for LICs the results suggest that increase in openness in the last period is associated with an increase in productive expenditures in the current period.

\subsection{Imports and Exports}

Next we separately investigate the causal relationship between the two components of trade openness, imports and exports, and the composition of government expenditures. Table 5 provides the results of the estimating regression equation (1) with logarithm of the ratio of government total, productive or unproductive expenditures to GDP as the dependent variables $(y)$ and the logarithm of the ratio of import to GDP as the explanatory variable $(x)$.

Table 5. Causality tests for imports and total, productive and unproductive expenditures

\begin{tabular}{|c|c|c|c|c|c|c|c|c|c|}
\hline \multirow[b]{2}{*}{ Variable } & \multicolumn{3}{|c|}{ All Countries } & \multicolumn{3}{|c|}{ Low Income Countries } & \multicolumn{3}{|c|}{ High Income Countries } \\
\hline & Total & Prod & Unprod & Total & Prod & Unprod & Total & Prod & Unprod \\
\hline \multirow[t]{2}{*}{ L1.import } & -0.030 & 0.705 & -0.460 & 0.394 & 0.460 & 0.422 & -0.589 & 0.957 & 0.049 \\
\hline & $(0.51)$ & $(0.28)^{* *}$ & $(1.21)$ & $(0.11)^{* * *}$ & $(0.15)^{* * *}$ & (1.14) & $(0.25)^{* *}$ & $(0.21)^{* * *}$ & $(0.33)$ \\
\hline \multirow[t]{2}{*}{ L2.import } & 0.052 & -0.116 & 0.079 & -0.090 & -0.032 & -0.782 & 0.279 & -0.286 & -0.082 \\
\hline & $(0.18)$ & $(0.09)$ & $(0.42)$ & $(0.21)$ & $(0.19)$ & $(0.49)$ & $(0.18)$ & $(0.13)^{* *}$ & $(0.15)$ \\
\hline Observations & 184 & 184 & 164 & 71 & 71 & 54 & 113 & 113 & 110 \\
\hline Countries & 68 & 68 & 63 & 30 & 30 & 25 & 38 & 38 & 38 \\
\hline Instruments & 14 & 14 & 14 & 14 & 14 & 14 & 14 & 14 & 14 \\
\hline Hansen $p$-value & 0.31 & 0.46 & 0.75 & 0.24 & 0.34 & 0.41 & 0.76 & 0.64 & 0.10 \\
\hline AR2 p-value & 0.59 & 0.07 & 0.96 & 0.83 & 0.24 & 0.26 & 0.44 & 0.09 & 0.72 \\
\hline \multicolumn{10}{|c|}{ Causality tests (p-values) } \\
\hline Test $\beta_{1}=\beta_{2}=0$ & 0.95 & 0.04 & 0.88 & 0.00 & 0.01 & 0.13 & 0.07 & 0.00 & 0.58 \\
\hline
\end{tabular}

For the estimation using data for all countries we find no evidence of a causal relationship between imports and total expenditures or unproductive expenditures. However, there is evidence of positive causal relationship between imports and productive expenditures. For LICs we find evidence of a positive causal relationship between imports and total government expenditures and productive expenditures but not between imports and unproductive expenditures. However, for HICs we find a positive causal relationship between imports and productive expenditures, but evidence of a weak negative causal relationship (significant at the 7\% level) between imports, and total expenditures and no evidence of a causal relationship between openness and unproductive expenditures. The results indicate that for HICs the components of expenditure not classified as productive or unproductive expenditures (about 18\% of government expenditures, which is $6 \%$ of the GDP, for HICs is not part of productive or unproductive expenditures, Table 1) have a negative causal relationship with imports and this results in our finding of a weak negative causal relationship between aggregate expenditure and imports. In sum, we find that imports have a positive causal relationship with productive government expenditures for both low-income and high-income countries.

Table 6 provides the results of the estimating regression equation (1) with logarithm of the ratio of government total, productive or unproductive expenditures to GDP as the dependent variables $(y)$ and the logarithm of the ratio of export to GDP as the explanatory variable $(x)$. For the estimation including data for all countries we find no evidence of a causal relationship between exports and total or productive or unproductive expenditures. Similar results are obtained for the LIC sample. For HICs we find some evidence of negative causal relationship between exports and total expenditures. However, there is no evidence of a causal relationship between exports and productive or unproductive expenditures. 
Table 6. Causality tests: exports and total, productive and unproductive expenditures

\begin{tabular}{lccccccccc}
\hline & \multicolumn{3}{c}{ All Countries } & \multicolumn{3}{c}{ Low Income Countries } & \multicolumn{3}{c}{ High Income Countries } \\
\cline { 2 - 11 } Variable & Total & Prod & Unprod & Total & Prod & Unprod & Total & Prod & Unprod \\
\hline L1.export & -0.098 & 0.168 & -0.473 & 0.106 & -0.122 & 0.500 & -0.291 & 0.021 & -0.563 \\
& $(0.27)$ & $(0.27)$ & $(0.71)$ & $(0.24)$ & $(0.34)$ & $(0.49)$ & $(0.13)^{* *}$ & $(0.75)$ & $(0.47)$ \\
L2.export & 0.109 & 0.076 & 0.159 & 0.094 & 0.209 & -0.407 & 0.153 & 0.048 & 0.140 \\
& $(0.08)$ & $(0.08)$ & $(0.20)$ & $(0.14)$ & $(0.15)$ & $(0.33)$ & $(0.10)$ & $(0.23)$ & $(0.22)$ \\
Observations & 184 & 184 & 164 & 71 & 71 & 54 & 113 & 113 & 110 \\
Countries & 68 & 68 & 63 & 30 & 30 & 25 & 38 & 38 & 38 \\
Instruments & 14 & 14 & 14 & 14 & 14 & 14 & 14 & 14 & 14 \\
Hansen p-value & 0.25 & 0.25 & 0.74 & 0.42 & 0.89 & 0.22 & 0.67 & 0.16 & 0.12 \\
AR2 p-value & 0.69 & 0.96 & 0.90 & 0.62 & 0.57 & 0.11 & 0.37 & 0.56 & 0.67 \\
Causality tests (p-values) & & & & & & & & 0.06 & 0.49 \\
Test $\beta_{l}=\beta_{2}=0$ & 0.41 & 0.48 & 0.71 & 0.49 & 0.37 & 0.45 & 0.06 & 0.96 & \\
\hline
\end{tabular}

Note. export is export to GDP ratio. Standard errors in parenthesis below estimates; *Significant at $10 \%$, **Significant at $5 \%$, and *** Significant at $1 \%$. Other definitions see Notes to Table 4 .

Overall, we conclude that the causal relationship between trade and government expenditures is through the relationship between imports and expenditures. Exports are not causally related to government expenditures. Government productive expenditures respond more to changes in imports but do not respond to exports. Our findings do not support the hypothesis in Rodrik (1998) that an increase in exports results in higher risk and therefore an increase in government size, the safe activity. The results however, do provide evidence in favor of an alternative mechanism for the relationship between government size and openness. In particular, greater imports as a share of GDP result in a greater demand for governments to increase productive expenditure to counteract the negative consequences from more exposure to imported goods.

The results of the current paper are thus consistent with a growing empirical literature that finds a positive relationship between openness and government size for reasons others than those suggested by Rodrik (1998). Recent studies by Epifani and Gancia (2009) and Hanslin (2010) are two such examples. Further, consistent with the literature we find that there are differences in the relationship between openness and government expenditures across different sets of countries. This confirms previous work by Alesina and Warcziarg (1998), Epifani and Gancia (2009), Garen and Trask (2005), Hanslin (2010), who have concluded that there are differences between groups of countries; in particular, between low-income and high-income countries.

\section{Conclusion}

This paper examines the causal relationship between greater exposure to international trade and the size and composition of government expenditures across low-income and high-income countries. Three variables are used to measure greater exposure to international trade, the ratio of the sum of exports plus imports to GDP, the ratio of exports to GDP and the ratio imports to GDP. These three measures are intended to capture differential impacts on how government may respond to greater openness. For example, in countries where imports have been growing, governments are often pressured to respond to the perceived lose of jobs and/or domestic production by spending more on either social services to compensate for the negative impact of greater foreign competition and buffeting citizens negatively affected by job or income lose, or by increasing spending on investment services and infrastructure to raise productivity and generate greater economic growth. Much of the analysis in the literature has centered on the notion that governments spend more on social services in response to greater openness. This paper however, considers the possibility that governments may spend more on productive expenditures, investment services, in response to greater openness.

The findings of the paper suggest that that there is no causal relationship between the openness (ratio of the sum of exports and imports to GDP) and government spending for high income countries regardless of the type of government expenditures. In the case of low-income countries, however, there is a positive causal relationship between openness and productive government expenditures. Our analysis further indicates that the primary source of this relationship in low-income countries is due imports and not exports. Similarly, for high-income countries there is a positive causal relationship between imports and productive expenditures. Governments in both low-income and high-income countries respond to higher imports by spending more on productive expenditures. This suggests that to counteract the negative impact of greater imports on their economies governments increase productive expenditures to raise capital productivity and generate additional economic growth. These results partially confirm Rodrik's (1998) hypothesis of openness leading to greater government 
expenditures though the link seems to generally occur through imports and lead to higher spending on productive rather than unproductive expenditures.

\section{References}

Alesina, A., \& Waczriag, R. (1998). Openness, country size and government. Journal of Public Economics, 69, 305-321. https://doi.org/10.1016/S0047-2727(98)00010-3

Arellano, M., \& Bover, O. (1995). Another look at the instrumental variable estimation of error-components models. Journal of Econometrics, 68, 29-51. https://doi.org/10.1016/0304-4076(94)01642-D

Autor, D. H., David, D., \& Gordon, H. H. (2013). The China Syndrome: Local Labor Market Effects of Import Competition in the United States. American Economic Review, 103, 2121-68. https://doi.org/10.1257/aer.103.6.2121

Barro, R. J. (1990). Government spending in a simple model of endogenous growth. Journal of Political Economy, 98, S103-S125. https://doi.org/10.1086/261726

Benarroch, M., \& Pandey, M. (2012). The Relationship between Trade Openness and Government Size: Does disaggregating government expenditure matter. Journal of Macroeconomics, 34, 239-252. https://doi.org/10.1016/j.jmacro.2011.11.002

Benarroch, M., \& Pandey, M. (2008). Trade Openness and Government Size. Economics Letters, 101, 157-159. https://doi.org/10.1016/j.econlet.2008.06.016

Blundell, R., \& Bond, S. (1998). Initial conditions and moment restrictions in dynamic panel data models. Journal of Econometrics, 87, 115-43. https://doi.org/10.1016/S0304-4076(98)00009-8

Cameron, D. R. (1978). The Expansion of the Public Economy: A Comparative Analysis. American Political Science Review, 72, 237-269. https://doi.org/10.2307/1954537

Casu, B., \& Girardone, C. (2009). Testing the relationship between competition and efficiency in banking: A panel data analysis. Economics Letters, 105, 134-137. https://doi.org/10.1016/j.econlet.2009.06.018

Cavallo, A. F., \& Cavallo, E. A. (2010). Are crises good for long-term growth? The role of political institutions. Journal of Macroeconomics, 32, 838-857. https://doi.org/10.1016/j.jmacro.2010.01.006

Cavallo, E. (2007). Openness to Trade and Output Volatility: A reassessment. Inter-American Development Bank Research Department Working Paper \#604.

Chang, R., Kaltani, L., \& Loayza, N. V. (2009). Openness can be good for growth: The role of policy $\begin{array}{lllll}\text { complementarities. Journal of Development } & \text { Economics, } & 90, & 33-49 .\end{array}$ https://doi.org/10.1016/j.jdeveco.2008.06.011

Dreher, A., Sturm, J. E., \& Ursprung, H. W. (2006). The Impact of Globalization on the Composition of Government Expenditures: Evidence from Panel Data. Cesifo Working Paper No: 1755.

Easterly, W. (2001). The Lost Decades: Developing Countries' Stagnation in Spite of Policy Reform 1980-1998. Journal of Economic Growth, 6, 1381-4338. https://doi.org/10.1023/A:1011378507540

Epifani, P., \& Gancia, G. (2009). Openness, Government Size and the Terms of Trade. The Review of Economic Studies, 76, 629-668. https://doi.org/10.1111/j.1467-937X.2009.00546.x

Garen, J., \& Trask, K. (2005). Do More Open Economies Have Bigger Governments? Another Look. Journal of Development Economics, 77, 533-551. https://doi.org/10.1016/j.jdeveco.2004.04.002

Garrett, G. (2001). Globalization and Government Spending around the World. Studies in Comparative International Development, 35, 3-29. https://doi.org/10.1007/BF02732706

Gemmell, N., Kneller, R., \& Sanz, I. (2008). Foreign Investment, International Trade, and the Size and Structure of Public Expenditures. European Journal of Political Economy, 24, 151-71. https://doi.org/10.1016/j.ejpoleco.2007.06.004

Ghali, K. H. (1999). Government size and economic growth: Evidence from a multivariate cointegration analysis. Applied Economics, 31, 975-987. https://doi.org/10.1080/000368499323698

Grossman, G., \& Helpman, E. (1990). Comparative Advantage and Long-run Growth. American Economic Review, 80, 796-815.

Hanslin, S. (2010). Trade Openness, Gains from Variety and Government Spending. SOI - Working Papers 1004, Socioeconomic Institute - University of Zurich. 
Hartwig, J. (2010). Is health capital formation good for long-term economic growth? - Panel Granger-causality evidence for OECD countries. Journal of Macroeconomics, 32, 314-325. https://doi.org/10.1016/j.jmacro.2009.06.003

International Monetary Fund. (2001). Market Access for Developing Countries' Exports. Retrieved from https://www.imf.org/external/np/madc/eng/042701.htm

Islam, M. Q. (2004). The Long Run Relationship Between Openness and Government Size: Evidence from Bounds Tests. Applied Economics, 36, 995-1000. https://doi.org/10.1080/0003684042000233221

Kneller, R., Bleaney, M. F., \& Gemmell, N. (1999). Fiscal policy and growth: Evidence from OECD countries. Journal of Public Economics, 74, 171-190. https://doi.org/10.1016/S0047-2727(99)00022-5

Levine, R., \& Renelt, D. (1992). A sensitivity analysis of cross-country growth regressions. American Economic Review, 82, 942-963.

Liberati, P. (2007). Trade Openness, Financial Openness and Government Size. Journal of Public Policy, 27, 215-247. https://doi.org/10.1017/S0143814X07000670

Michauda, P., \& van Soest, A. (2008). Health and wealth of elderly couples: Causality tests using dynamic panel data models. Journal of Health Economics, 27, 1312-1325. https://doi.org/10.1016/j.jhealeco.2008.04.002

Molana, H., Montagna, C., \& Violato, M. (2004). On the Causal Relationship between Trade-openness and Government Size: Evidence from 23 OECD Countries. University of Dundee Discussion Paper no. 164.

Panagariya, A. (2003). Think Again: International Trade. Institute of Public Affairs Review, 55, 14-17.

Ram, R. (2009). Openness, country size, and government size: Additional evidence from a large cross-country panel. Journal of Public Economics, 93, 213-218. http://dx.doi.org/10.1016/j.jpubeco.2008.04.009

Rivera-Batiz, L. A., \& Romer, P. M. (1991). Economic integration and endogenous growth. The Quarterly Journal of Economics, 106(2), 531-555. https://doi.org/10.2307/2937946

Rodrik, D. (1998). Why do more open economies have bigger governments? Journal of Political Economy, 106, 997-1032. https://doi.org/10.1086/250038

Romer, P. M. (1986). Increasing returns and long-run growth. Journal of Political Economy, 94, 1002-1037. https://doi.org/10.1086/261420

Romer, P. M. (1990). Endogenous technological change. Journal of Political Economy, 98, S71-S102. https://doi.org/10.1086/261725

Roodman, D. (2009a). How to do xtabond2: An introduction to difference and system GMM in Stata. Stata Journal, 9, 86-136.

Roodman, D. (2009b). Practitioner's Corner: A note on the theme of too many instruments. Oxford Bulletin of Economics and Statistics, 71, 135-158. https://doi.org/10.1111/j.1468-0084.2008.00542.x

Santos-Paulino, A. and A.P. Thrlwall (2004). The Impact of Trade Liberalisation on Exports, Imports and the Balance of Payments of Developing Countries. The Economic Journal, 114, F50-F72. https://doi.org/10.1111/j.0013-0133.2004.00187.x

Windmeijer, F. (2005). A finite sample correction for the variance of linear efficient two-step GMM estimators. Journal of Econometrics, 126, 25-51. https://doi.org/10.1016/j.jeconom.2004.02.005

World Bank. (2010). World Development Indicators 2010. World Bank: Washington, Chapter 6. https://doi.org/10.1596/978-0-8213-8232-5

Yanikkaya, H. (2003). Trade openness and economic growth: A cross-country empirical investigation. Journal of Development Economics, 72, 57-89. https://doi.org/10.1016/S0304-3878(03)00068-3

\section{Notes}

Note 1. See for example, Alesina and Warcziarg (1998), Ashraf, Herzer and Nunnenkamp (2016), Garett (2001), Islam (2004), Molana, Montagna and Violato (2004), Cavallo, (2007), Liberati (2007), Garen and Trask (2005), Benarroch and Pandey (2008), Epifani and Gancia (2009) and Hanslin (2010) to name a few.

Note 2. Given availability of panel data and the flexible properties of these models, they have been used by a number of recent studies examining causality between variables (Benarroch \& Pandey, 2012; Casu \& Girardone, 2009; Hartwig, 2010; Michauda \& van Soest, 2008; among others). 
Note 3. See Easterly (2001) for further details. The data has been posted on the World Bank website as part of the Global Development Network Growth Database and was downloaded using the following url: http://econ.worldbank.org/WBSITE/EXTERNAL/EXTDEC/EXTRESEARCH/0,,contentMDK:20701055 page PK:64214825 piPK:64214943 theSitePK:469382,00.html

Note 4. Another measure that has been used in recent studies is financial integration (Garret \& Mitchell, 2001; Kose et al., 2008; Kimakova, 2009; Benarroch \& Pandey, 2012).

Note 5. Only for two specifications for the import measure the AR2 test is not satisfied; the null hypothesis of second-order serial correlation is accepted at the $10 \%$ level of significance.

\section{Appendix A}

\section{Country Codes}

Table A1. Countries used for the analysis over the 1972-2000 period: Total 68 countries (LIC 30 countries HIC 38 countries)

\begin{tabular}{|c|c|c|c|}
\hline Country & LIC & Country & LIC \\
\hline Argentina & 0 & Kuwait & 0 \\
\hline Australia & 0 & Lesotho & 1 \\
\hline Austria & 0 & Liberia & 1 \\
\hline Bahamas, The & 0 & Luxembourg & 0 \\
\hline Bahrain & 0 & Malaysia & 0 \\
\hline Barbados & 0 & Maldives & 1 \\
\hline Belgium & 0 & Mali & 1 \\
\hline Bolivia & 1 & Malta & 0 \\
\hline Brazil & 0 & Mauritius & 0 \\
\hline Bulgaria & 1 & Mexico & 0 \\
\hline Burkina Faso & 1 & Morocco & 1 \\
\hline Cameroon & 1 & Nepal & 1 \\
\hline Canada & 0 & Netherlands & 0 \\
\hline Chile & 0 & Norway & 0 \\
\hline Colombia & 1 & Pakistan & 1 \\
\hline Costa Rica & 0 & Panama & 0 \\
\hline Cote d'Ivoire & 1 & Paraguay & 1 \\
\hline Cyprus & 0 & Romania & 1 \\
\hline Denmark & 0 & Senegal & 1 \\
\hline Dominican Republic & 1 & Singapore & 0 \\
\hline Egypt, Arab Rep. & 1 & Spain & 0 \\
\hline Ethiopia & 1 & Sri Lanka & 1 \\
\hline Finland & 0 & Sweden & 0 \\
\hline France & 0 & Syrian Arab Republic & 1 \\
\hline Greece & 0 & Thailand & 1 \\
\hline Guyana & 1 & Togo & 1 \\
\hline Hungary & 0 & Tunisia & 1 \\
\hline India & 1 & Turkey & 0 \\
\hline Indonesia & 1 & United Kingdom & 0 \\
\hline Iran, Islamic Rep. & 1 & United States & 0 \\
\hline Ireland & 0 & Uruguay & 0 \\
\hline Israel & 0 & Venezuela & 0 \\
\hline Italy & 0 & Yemen, Rep. & 1 \\
\hline Korea, Rep. & 0 & Zimbabwe & 1 \\
\hline
\end{tabular}

\section{Copyrights}

Copyright for this article is retained by the author(s), with first publication rights granted to the journal.

This is an open-access article distributed under the terms and conditions of the Creative Commons Attribution license (http://creativecommons.org/licenses/by/4.0/). 